\title{
Analysis on article 15 of China accession protocol after expiration
}

\author{
Yan Yang \\ Nanjing University of Science and Technology, China \\ 1677440434@qq.com
}

\begin{abstract}
In 2017, with the expiration of Article 15 in China's accession to the World Trade Organization (WTO), the issue of China's full market economy status has received significant attention from public and government. This paper makes an objective interpretation of the content about Article 15 in Protocol and the identify rules of market economy status, reversing the misunderstanding. Finally, we summarize the current situation on basis of all above analysis, then give strategies and recommendations related to government or enterprise.
\end{abstract}

Key words: protocol on the accession of the PRC; surrogate country; market economy status; WTO

\section{Introduction}

'Non-market economy status' has been the core chips for WTO member countries to apply trade remedy measures against China's for years, affecting all aspects of China. Now with the expiration of Article 15 in Protocol, the United States and Japan and other countries still refuse to recognize China's market economy status has aroused widespread concern of scholars at home and abroad.

The focus of this paper is slightly different. No matter whether China's market economy status is recognized or not, ${ }^{1}$ there is a common misunderstanding in the interpretation and comprehension of article 15 for domestic public. The definition and criteria of 'market economy status' are derived from domestic trade legislation of WTO members, such as European countries and the United States. From GATT to the relevant legal documents of WTO, there has never been a criterion for non-market economy countries, and the so-called Article 15 in protocol is no exception.

Therefore, as a part of the masses, ${ }^{2}$ we should keep a clear mind and take rational attitude to look upon this issue. Recognizing the status of China's market economy should not be confused with carrying out Article 15 of Protocol earnestly, which is the crux of this paper. 


\section{Interpretation and controversy about Article $\mathbf{1 5}$}

\subsection{Background}

Looking back on China's accession to the WTO, it has been a long and difficult 15-year. From July 1986, China formally applied for the recovery of GATT contractor status, to November 2001, the United Nations considered and adopted the decision of China's accession to WTO. In the past 15 years, negotiations about China's rejoining the GATT and accession to the WTO had no progress at a certain period of time. ${ }^{3}$ Since major countries had no confidence in China about carrying out WTO agreements, as well as the imperfect development of China's market economy, we had to make some tactical concessions, otherwise the day China joining WTO will be in the invisible future

Article 15 in protocol is born in this background. As a strategic term, it's obviously a skill of retreating in order to advance.

\subsection{Textual interpretation}

Article 15 of protocol on the accession of the PRC can be divided into four parts, here we focus on paragraph a and d cause they are quite controversial in current situation.

First, judging from the title 'Price Comparability in Determining Subsidies and Dumping', it obviously didn't refer to any criteria about 'market economy status' in Article 15. Also, what calls for special attention is that WTO agreements had never appeared any clauses on how to judge a country's market economy status. ${ }^{4}$ It kept the discretionary power to all WTO members, which resulting in the arbitrariness and subjectivity of judgment for different country.

Second, paragraph a in Article 15 made a provision in procedures when products importing from China entering into WTO member states, which is mainly for how to determine the price comparability when the WTO members carry out anti-dumping investigations on products from China. It was divided into two points:

(i) said that if the Chinese manufacturer can clearly prove that the production of similar products in manufacturing, production and sale was qualified with market economy conditions, then importing member should use Chinese prices or costs of the surveyed industry to compare.

(ii) is another supplement. That's is to say, in the absence of a clear proof, WTO importing member could use a methodology that is not based on a strict comparison with domestic prices or costs in China, which means adopting substitute country's reference price. It is this discriminatory clause that makes China suffer from western countries' anti-dumping 
investigations for years.

Paragraph b refers to relevant provisions of countervailing investigation when Chinese products were exported into WTO Member State. Paragraph c make the provisions for implementing procedures. It points out that importing WTO Member shall notify the WTO Anti-Dumping and Countervailing Measures Committee when carrying out the relevant measures.

Finally, what needs detailed interpretation is paragraph d. It restricts the applicability of Article 15's discriminatory content, which is the core and focus of this paper. It has two restrictions. First, once China could confirm its market economy status under the national law of the importing WTO Member, then paragraph (a) shall be terminated. But the premise is by the date of joining, WTO member's domestic law should include the criteria for judging market economy. Second, in any event, the provisions of subparagraph (a)(ii) shall expire 15 years after the date of accession. ${ }^{5}$ It is clear from this point that not the 'non-market economy status' clause becomes due, but the measure of substitute country's reference price is expired.

\subsection{Debates on Article 15 at home and abroad}

\subsubsection{Insist that China's market economy status should be recognized}

Since joining the WTO, China has frequently developed diplomatic activities with other WTO members to strive for their recognition of China's market economy status. So far, more than 80 WTO members have accepted China's market economy status.

Besides, in terms of the entire academic community, scholars who insist that China's market economy status should be recognized are not a few.

On April 11, 2016, a study provided by the Peterson Institute said that the legal services department of European Commission decided that, according to WTO rules, the European Union has the obligation to confer China the status of market economy. Moreover, EU Trade Commissioner Cecilia Malmström stressed that whether to grant China the market economy status depends on the 15-year deadline in the protocol on the Accession of the PRC, rather than whether China has achieved the market economy standards or not. Refusing to grant China the market economic status, in fact, is a strict legal issue.

The same year on June 22, American Brookings Institution said that problem of China's market economy status in Europe is more complex, because refusing to recognize it will be contrary to the rule of law in the European Union.

This was also mentioned in some earlier academic reports. For example, ${ }^{6}$ Usha Ha-ley in West Virginia University wrote her article 'Subsidies to Chinese Industry: State Capitalism, 
Business Strategy and Trade Policy' and considered that, China's non-market economy status will expire in 2016, at that time these terms will cease to take effect. Author expressed the relationship between the failure of Article 15 and the maturity of China's non-market economy status. She argued that under the current US laws, the inverse of 'non-market economy status' is the 'market economy status'. Non-market economy status expires, which just means that the coming of market economy status.

Another example, when faced with the disputation about 'market economy status' automatically expires from some domestic and foreign scholars, ${ }^{7}$ Professor Gao (Henry Gao) used pure text analysis and pointed out that in determining the price comparability, there are only two options: a(i) applying Chinese prices and costs, or a(ii) taking alternative country's price by determining China’s non-market economy status. Since a (ii) as a special method of judging non-market economy has expired after 15 years, then it will be produced to give China market economy status as the actual effect.

\subsubsection{Deny China's market economy status automatically recognized when expired}

In December 11, 2016, with the expiration of a 15-years 'sunset clause', whether China could acquire market economy status or not has brought grate concern. But the United States, Japan and some other countries have recently expressed their reluctant willing to recognize China's market economy status.

On December 8, 2016, Japan's Ministry of Economy and Industry said that considering China's position in the WTO, they continue to insist China as a non-market economy country because China has not yet solved the problem of excess capacity in state-owned enterprises. The United States even made a high-profile announcement about it through a well-known financial media, CNBC TV. They declared that the Obama administration will not confer China as market economy country.

This situation is not unexpected. As early as 2011, some scholars had refuted the opinion that China's market economy status automatically acquired after expiration. The representative of European scholars is ${ }^{8}$ Bernard O'Connor. He expounded the arguments he held from the perspective of the law and the facts. They considered that China automatically acquires market economy status in the end of 2016 is an unrealistic delusion and a wrong way to interpret.

Objectively speaking, neither the WTO agreements nor the protocol had clearly expressed that China can automatically obtain market economy status, also they didn’t prohibit other 
member states from identifying that China still do not have market economy status. So Connor's point of view is correct to some extent. That's why after Connor the consensus of automatic recognition no longer exists. The interpretation of article 15 comes into a new stage of argument ever since.

\section{Analysis and summary of the current situation (based on Article 15 in Protocol)}

\subsection{Centralized contradiction and tense situation}

From the above analysis, it is clear that the conflicts and disputes are concentrated on the recognition of China's market economy status in current situation.

According to the interpretation of Article 15, ${ }^{9}$ America and Japan do not recognize China's market economy status according to Article 15 a (i). They grasp the discretionary power of market economy status which is granted by WTO and insists that China has not yet reached the standard of market economy country which is defined by their domestic law. Whereas the anger of Chinese government and public comes from the restriction clause of Article 15 paragraph d. That is, in any case, the provisions of paragraph a (ii) shall expire 15 years after the date of China's accession to the WTO.

In current situation, ${ }^{10}$ China's major public platforms, including NetEase, Tencent and other operators, have condemned the United States and Japan for their behavior of refusing to recognize China's market economy status. They published quite a lot articles to fair decision and garnered such massive media attention. Now more and more Chinese people are strongly dissatisfied with the attitude of the United States and Japan.

\subsection{Focus dislocation and rational speech}

What is the sunset clause? ${ }^{11}$ Does it mean China's non-market economy status come to an end? I think that's not the case.

Paragraph $\mathrm{d}$ in Article 15 of the Protocol makes a definite termination for a(ii), the subrogate country system which has not yet been concerned by public. It directly led to China becoming the biggest victim of discriminatory anti-dumping duties.

When WTO members especially the United States launch anti-dumping actions against China, considering certain political factors and the purpose of domestic trade protection, the choice of alternative countries is often quite arbitrary and discriminatory for importing countries. So, in order to confirm the dumping of China's export products, they often choose countries that are quite different from China in economic patterns and industry conditions as subrogate countries. The direct consequence is that the normal value of China's export 
products is greatly overestimated. Therefore, ${ }^{12}$ the original 'dumping' behavior has been verified in a distorted form. Similar cases are too numerous to list and this is where we really need to pay attention.

To sum up, the behavior that American and Japan do not recognize China's market economy status cannot be regarded as a breach of contract, because WTO has given members the discretion to define market economy status. But if after that, they still adopt the surrogate country method into anti-subsidy investigations on China. That will be the breach of contract. We must not be led by the wrong direction of public opinion and it's time for us to pay attention to rational speech.

\subsection{Grasp the opportunity and take active measures}

Since China joined the WTO in 2001, we have been the country with the largest number of trade remedy measures during the past 15 years. What's worse, international community gradually formed the situation of established powers versus China. ${ }^{13}$ Due to the existence of discriminatory provisions a(ii), the randomness of choosing subrogate country has made it quite easy for these countries to impose anti-dumping measures on China. High anti-dumping duties have directly hindered the export of certain industries in China.

In this situation, the expiration of Article 15 is undoubtedly an opportunity for China. As a responsible major power, we should make rational use of the rights granted to us by WTO rules when we earnestly fulfill our obligations, and take active attitude to confront the upcoming challenges. If necessary, we can bring up the dispute settlement mechanism to WTO and take action against other countries' discriminatory anti-dumping measures. China must seize the initiative in negotiations.

\section{Policies and recommendations}

\subsection{Apply for amendment about the ambiguous content in protocol}

After the expiration of the 'sunset clause' Article 15, a(ii) is invalid but a(i) still takes effect. However, its meaning is not clear enough.

The main content of a(i) is as follows:

If producers under investigation can clearly show that market economy conditions prevail in the industry producing the like product with regard to the manufacture, production and sale of that product, the importing WTO Member shall use Chinese prices or costs for the industry under investigation in determining price comparability.

So, what is the standard of 'clear show' in the above text? And what are the market economy 
conditions?

Obviously, there is no standard visibility definition. So, it is easily exploited by some WTO members especially the United States, as the basis of ${ }^{14}$ anti-dumping investigations for China. Hence, with the expiration of discriminatory contracts, China should seize the rare opportunity and actively propose to amend and supplement the relevant provisions to safeguard our rights and benefits.

\subsection{Keep peace of mind even without being recognized}

Nowadays, the issue of China's market economy status is quite internationally controversial.

${ }^{15}$ Although more than 80 WTO members have recognized this fact under the efforts of China's foreign ministry, but a number of countries led by the United States still hold a strong negative attitude. About this, neither criticizing severely nor begging piteously is wise behavior. From the viewpoint of policy stance and economic interests, the United States is unlikely to give up the chip of non-market economy. Even the subrogate country practices may continue in disguised form.

In addition, ${ }^{16}$ we also need to be clear that even if China's market economy status is recognized by all WTO members, it doesn't mean that anti-dumping investigations will be terminated. ${ }^{17}$ Nor does it mean that our export enterprises could definitely use the cost and price provided by themselves to calculate normal value of export commodities when they encounter anti-dumping investigations".

For example, ${ }^{18}$ last year Russia lodged an appeal to WTO for the European Union taking anti-dumping measures of cold rolled coil. Although Russia’s market economy status has been recognized by the European Union, EU still refused to use the cost in Russian producer's financial records to calculate the dumping margin and took the policy of special market situation as the reason. By raising the target profit margins, the European Union successfully doubled Russia's anti-dumping tax rate, which made Russia's corporate tax rate rise from $26.2 \%$ in preliminary decision $26.2 \%$ to $36.1 \%$ in final judge.

To sum up, what we Chinese really need to fight for is far more than just a simple slogan of China's market economy status. There is no necessary to get mad and lose mind simply because of some countries' denial attitude.

\subsection{Emphasize the general obligations of WTO members and cancel the discriminatory practices against China's}

With the expiration of paragraph a(ii) in protocol, local media chose to appeal for recognizing 
China's market economy status rather than emphasizing the WTO members stops using subrogate country method to account the cost. ${ }^{19}$ Of course, in order to prevent the United States and other countries from using the policy of special market conditions policy as reason, continue taking cost accounting methods of subrogate country, we should be prepared for a dispute case in advance and continue to further study WTO rules and laws.

\section{4 (For government) Uphold and deepen the reform, continuously improve the market economy level of our country}

To be frank, the reason why China suffers so many anti-dumping prosecution is also related to our market environment. There are many deficiencies such as the incomplete market economy, unbalanced economic development and imperfect industrial structure. So the United States and other WTO members could take different levels of trade remedy measures on the basis of discretionary power.

The reservation clause a(i) in Protocol states that if Chinese manufacturers can clearly demonstrate that the industry producing the same product has market economy conditions in the manufacture, production and sale of the product, then importing members should use the prices and costs of surveyed industry to compare.

From this point of view, the most fundamental solution is to actively promote the construction of China's market economic system. Government should handle the relationship with private enterprises properly, make sure the market-oriented development and reduce the intervention of prices and trade. Certainly, in order to avoid WTO members take the non-market economic as reasons to impose various anti-dumping means, we could also research the domestic law and market standards of importing countries to correct our own inadequacies, during the construction of the market economic system.

\section{5 (For enterprise) Change the labor-intensive mode of production, improve the core values of export products.}

${ }^{20}$ We should know that WTO members launched anti-dumping against China mainly because the price of China's export product is too low, which brought negative impact on their domestic industries. Typically, take the 'mouse phenomenon' as example, a wireless mouse that values $\$ 40$ only pays merely \$3 to the assembly plant in Suzhou, China. The labor force is too cheap for me to accept.

This phenomenon inspires our enterprises to accelerate transforming the mode of production, adjusting the industrial structure and enhancing the capacity of innovation. It is time for us to 
change the original labor-intensive mode of production and upgrade to capital-intensive or technology-intensive enterprises, which could help to improve the international competitiveness of China's products. In addition, developing foreign markets, encouraging domestic enterprises to go out and actively expanding foreign investment can be a good strategy too. Through the pattern of overseas acquisitions and mergers, we can transfer production base into the importers, which could save our domestic energy, reduce the environment pollution, and avoid the anti-dumping investigations. It is perfect to kill two birds with one stone.

Finally, besides their own development, there are many things that companies can do. Such as when encounters anti-dumping investigations, Chinese enterprises should actively prove that their production, manufacture and sale are under the conditions of the market economy. It is silly to sit and wait.

\section{References}

1 "Recognize China's market economy status" is a false proposition, China Foreign Investment, 2017.

2 Yang $X i$, Judgment about China's non-market economy status - from the perspective of the effectiveness when article 15 protocol expires, Jilin University, 2017.

3 Ding Yun. Research on expiration of China`s non market economy status and article 15 of protocol on the accession of the PRC, East China University of politics and law, 2015.

4 Nastoll, Barbara, EU Anti-dumping Law, imports from China and treatment of non-market economy countries, Common Market Law Review 265 (2013).

5 Liu Xuewen, Zhu Jingan, Predicament and breakthrough of non-market economy status in international trade remedy. Exploration of Economic Problems 4 (2015)

6 Usha Ha-ley. Subsidies to Chinese Industry: State Capitalism, Business Strategy and Trade Policy, 2013.

7 Henry Gao. 'If You Don’t Believe In the 2012 Myth, Do You Believe In the 2016 Myth?'

http://worldtradelaw.typepad.com/ielpblog/2011/11/if-you-dont-believe-in-the-2012myth-do-you-believe-in-the-2016-myth.html, last visited Jan. 24, 2015.

8 Bernard O’Connor. Market-economy status for China is not automatic. China and Market Economy StatusIII, 2012. http://worldtradelaw.typepad.com/ielpblog/2012/05/china-and-market-economy-statusiii.html. 
9 Li Siqi, Yao yuan, Tu Xinquan, The prospects of China acquire the market economy status in 2016: America factors and China strategies. International Trade Issues 3 (2016)

10 Jorge Miranda: Interpreting Paragraph 15 of China's Protocol of Accession. Global Trade and Customs Journal 9(3) 2014.

11 Peng Delei, Non-market economy status after 2016 - debate, exploration and anticipation, International Trade Issues 6 (2015)

12 Song Lifang, Anti-dumping friction against China and countermeasures. Strategy and Policy 2 (2012).

13 Liu Jianming, Yuan Yongyou. Some understandings of article 15 in Chinese protocol. Foreign Trade and Economic Practice 2 (2004)

14 Francis Snyder, The Origins of the 'Nonmarket Economy': Ideas, Pluralism \& Power in EC Anti-dumping Law about China. European Law Journal 369 (2001).

15 Wang Shengwei, Xu Kaihua, Jin Dong. The fifteenth article on protocol of China's accession to the WTO. Legal and Economy 2 (2006)

16 Xie Jianguo. Economic influence, political divergence and institutional friction -- An Empirical Study on US carrying out anti-dumpling investigations against China. Management World 12 (2006)

17 Bao Xiaohua, Evaluation on trade remedy effects of anti-dumping measures. Economic Research 2 (2007)

18 Bao Xiaohua, Did China experience discriminatory anti-dumping investigations? comparing with other exporting countries. Management World 3 (2011)

19 Kenneth J. Pierce and Matthew R. Nicely, Transitioning TO China’s Market Economy Antidumping Treatment in 2016. Global Trade and Customs Journal 4 (2014)

20 Francisco Urdinez, Gilmar Masiero, China and the WTO: Will the Market Economy Status Make Any Difference after 2016. 